\title{
Teaching good infection control practices with fun: impact of the serious game Flu.0
}

\author{
A-G Venier ${ }^{1 *}$, S Marie², T Duroux ${ }^{1}$, C Bervas ${ }^{1}$, P Parneix ${ }^{1}$ \\ From 3rd International Conference on Prevention and Infection Control (ICPIC 2015) \\ Geneva, Switzerland. 16-19 June 2015
}

\section{Introduction}

Flu outbreaks usually reveal that practices and knowledge about the diagnosis of influenza, its treatment and infection control measures must be improved. A serious game, "Flu. 0 ", was created to teach the 8 key points to know and do when facing one or more patient infected by influenza.

\section{Objectives}

To evaluate the impact of playing to 'Flu.0' on the knowledge and practices of nurses and physicians.

\section{Methods}

Flu.0 is free and can be played online or downloaded; A call for participation to play and evaluate the game was performed. Players were asked to complete a questionnaire before and after the game to give their opinion on sentences about flu, to write what they learned with the game and the main thing they would do differently. A descriptive analysis was performed and the evolution of the answers was analysed.

\section{Results}

Physicians were 264 to participate (including 213 fellows), senior nurses 62 and nurses students 577; 95\% learnt at least something. The main knowledge acquired was about rapid test for influenza (32\%) and additional precautions (19\%). Significantly, players agreed more after the game that seasonal flu is a not benign disease, that flu vaccination of health care workers is useful, knew more about antiviral treatment and felt better prepared to face a flu case $(\mathrm{p}<0.001)$. Thanks to the game $47 \%$ of physician/senior nurses and $80 \%$ of nurses students declared they would perform better additional precautions.

${ }^{1}$ CCLIN SUD-OUEST, Bordeaux, France

Full list of author information is available at the end of the article

\section{Conclusion}

A serious game is an innovative quick and efficient tool for infection control team to improve patient safety.

\section{Disclosure of interest}

None declared.

\section{Authors' details}

${ }^{1}$ CCLIN SUD-OUEST, Bordeaux, France. ${ }^{2}$ ARLIN Limousin, Limoges, France.

Published: 16 June 2015

doi:10.1186/2047-2994-4-S1-I10

Cite this article as: Venier et al:: Teaching good infection control practices with fun: impact of the serious game Flu.0. Antimicrobial Resistance and Infection Control 2015 4(Suppl 1):110.

\section{Submit your next manuscript to BioMed Central and take full advantage of: \\ - Convenient online submission \\ - Thorough peer review \\ - No space constraints or color figure charges \\ - Immediate publication on acceptance \\ - Inclusion in PubMed, CAS, Scopus and Google Scholar \\ - Research which is freely available for redistribution

\section{() Biomed Central}

